\begin{tabular}{|c|c|c|c|}
\hline $\begin{array}{c}\text { Al_FARABI } \\
\text { http://dergipark.gov.tr/farabi }\end{array}$ & $\begin{array}{l}\text { International Journal on Social Sciences } \\
\text { ISSN 2564-7946 }\end{array}$ & & \\
\hline Arrival Date: 04.04 .2020 Published & \multirow{2}{*}{ DOI: 10.46291/AI-Farabi.050214 } & Volume (5) & Issue (2) \\
\hline Date: 31.05 .2020 & & Year (lu & e 2020) \\
\hline
\end{tabular}

Prof. Dr. Salih ÖZTÜRK ${ }^{1}$

Müşerref ÖNER ${ }^{2}$

\title{
Türkiye Ekonomisinde Enflasyon ile Faiz Oranları Arasındaki İlişki: 1980- 2018 Dönemi
}

\author{
Relationship Between Inflation and Interest Rates in the Turkish Economy: \\ 1980- 2018 Period
}

\begin{abstract}
ÖZET
$\mathrm{Bu}$ çalışmada, enflasyon ile faiz oranları arasında bulunan nedensellik ilişkisi incelenmiştir. Çalışmada Türkiye ekonomisi için 1980:1-2018:4 dönemine ilişkin veriler kullanılarak enflasyon oranları ile faiz oranları veri setleri kullanılmak üzere serilerin arasındaki ilişki EngleGranger Nedensellik analizi yöntemi ile tahmin edilmiştir. Yapılan analiz sonucuna göre logoritması alınmış seriler mevsimsel etkilerin varlığından arındırıldıktan sonra Phillips-Perron ve ADF birim Kök Testleri ile seriler durağanlaştırılmıştır. Engle Granger Nedensellik analizi uygulandıktan sonra Johansen eşbütünleşme analizi yapılarak enflasyon oranları ile faiz oranları arasında bulunan nedensellik ilişkisi tespit edilmeye çalışılmıştır. Analiz sonuçlarından elde edilen bulgulara göre enflasyon oranlarından faiz oranlarına doğru nedensellik ilişkisinin bulunduğu görülürken, faiz oranlarından enflasyon oranlarına doğru ise bir nedensellik ilişkisinin bulunmadığ 1 tespit edilmiştir.
\end{abstract}

Anahtar Kelimeler: Faiz oranları, enflasyon oranları, birim kök testi, Johansen eşbütünleşme testi

\begin{abstract}
In this study ,the causality relationship between inflation and interest rates is examined.Working for Turkey's economy in 2003: 1-2018: 4 period using data on inflation and interest rates were estimate dusing data sets Engle Granger causality relation ship between the series analys is method to be used. According to the results of the analysis, the series were logoritized and the series were stabilized by Phillips-Perron and ADF unit Root Tests. After applying Engle Granger Causality Analysis, Johansen cointegration analysis was conducted to determin the causality relation ship between inflation rates and interest rates. According to the finding sobtained from the analysis, it is observed that there is a causality relationship from inflation rates to interestrates, where as there is no causality relationship from interest rates to inflation rates.
\end{abstract}

Keywords: Interest rates, inflation rates, unitroot test, Johansen cointegration test

\footnotetext{
${ }^{1}$ (https://orcid.org/0000-0001-6851-951X), Tekirdağ Namık Kemal Üniversitesi, İktisadi ve İdari Bilimler Fakültesi, İktisat, e-mail: salihozturk@nku.edu.tr

${ }^{2}$ (https://orcid.org/0000-0002-7919-4682), TKÜ Sosyal Bilimler Enstitüsü İktsat ABD, muserref.onrr@gmail.com
} 


\section{GíRIŞ}

Enflasyon kavramı son dönemlerde özellikle gelişmemiş ve gelişmekte olan ülkelerde ortaya çıkan en önemli problemlerden biri olarak meydana gelmektedir. En basit ifade ile söylemek gerekirse fiyatlar genel düzeyindeki sürekli olarak artı̧̧ göstermekte olan enflasyon söz konusu ülkelerde yaşamakta olan bireylerin beraberinde alım güçlerindeki düşüşü ve giderek azalmakta olan gelirlerini göstermekte olan bir kavramdır. Ekonomide var olan enflasyon problemi ekonomik istikrarsızlığ yükselttiği gibi aynı zamanda ekonomik performansı da zayıf hale getirmektedir.

Yapılan çalışmada, eski bir tartışma konusu olan faiz oranı mı enflasyonu etkiler yoksa enflasyon mu faiz oranlarını etkiler sorularına yön vermesi açısından açıklanmaktadır. Genelde ekonomiler dikkate alındığında yüksek seviyedeki enflasyon oranları faiz oranında da yüksek düzeylerde belirlenmesine sebep olmaktadır. Bunun nedeni ise yüksek oranlarda enflasyonun meydana geldiği süreçlerde mal ve hizmetlerin fiyatında ortaya çıkan fiyatların değişimlerinin kontrolünün sağlanmasının zor olmasıdır. Bu gibi süreçlerde yatırım yapanlar karlarını hesaplamada zorluklar çekecekler ve kendilerine güvenilir bir ortam bulmak isteyeceklerdir. Bu bağlamda yatırımcılar risk almamak için ve yüksek bir getirisi olan araçlara yönelirler ve böyle bir durumda faizler artı̧̧ göstermektedir.

Bir ülkenin ekonomisinde, para politikası yürütmekle mükellef olan karar vericiler ve kurumların para politikasında meydana gelen değişimler, söz konusu ülkenin ekonomisinde faiz oranları ve enflasyon oranları üzerinden ekonomideki birimlerin gelecekteki dönemlerle ilgili verdikleri kararlarını önemli derecede etkilemektedir. Faiz oranlarının ve enflasyon beklentilerinin yükseliş yönünde değişeceğine yönelik beklentilerin ortaya çıktığı ekonomilerde, ekonomideki birimler gelecek dönemdeki yatırım ve tüketim kararlarını tekrardan gözden geçireceklerdir. Bu açıdan faiz oranları ve enflasyon oranları, uygulanmakta olan para ve istikrar programlarının en temelini meydana getirmekte ve bu söz konusu programların performanslarını ortaya koymaktadır. Uygulanan para politikası sonucunda faiz oranlarında ve enflasyon oranlarında ortaya çıkan değişmeler, ekonomiyi yakından ilgilendirmekte ve iki değişken bir ilişkinin bulunmasına yönelik araştırma ve tartışmaları da beraberinde getirmiştir. Nominal faiz oranları ile enflasyon oranları arasında bulunan ilişkinin varlığını açıklamaya yönelik yaklaşım Fisher Etkisi şeklinde ifade edilmektedir. Söz konusu yaklaşıma göre enflasyon oranlarında meydana gelen değişmelerin, nominal faiz oranlarını pozitif bir yönde etkilediği söylenmektedir.

Türkiye'de 2000'li yıllar itibariyle para politikaları uygulamalarında önemli değişiklikler gerçekleşmiştir. Bu açıdan fiyat istikrarının istikrarlı bir şekilde kalıcı olarak sağlanabilmesi için T.C. Merkez Bankası (TCMB), 2002 yılından sonra örtük, 2006 yılından sonra ise resmi bir şekilde günümüze kadar olan süreçte enflasyon hedeflemesi rejimi yürütülmektedir ve bununla birlikte enflasyon beklentileri oranı daha da düşük düzeylere çekilmiştir. Türkiye ekonomisinde para politikalarındaki uygulamalarda meydan gelen değişmeler, faiz oranları ve enflasyon oranları arasında bulunan ilişkinin tekrardan incelenmesini gerekli kılar. Türkiye'de nominal faiz oranları ile enflasyon oranları arasındaki ilişkinin incelendiği bu çalışmada ikinci bölümde, teorik çerçeve ve literatür taraması ele alınmaktadır. Üçüncü bölümünde, bu çalışmanın uygulama kısmında kullanılmakta olan yöntem hakkında bilgiler verilmiştir. Dördüncü bölümde ise, Türkiye'ye ilişkin zaman serisi analizine yönelik model ve veri seti belirlenip, ampirik bulgular değerlendirilmiştir.

\section{Enflasyon ve Faiz Kavramları Teorik Çerçevesi}

Enflasyon denince ilk akla gelen olgu, kullandığımız mal ve hizmet fiyatlarında ortaya çıkan artışlardır. Ancak dikkat edilmesi gereken bir durum meydana gelmektedir. Enflasyon kavramı; bir veya birden fazla mal ve hizmet fiyatında meydana gelen artış değil enflasyon sepetinde yer alan malların fiyatlarının artış göstermesidir. Dikkat edilmesi gereken bir durum meydana gelen fiyat artışlarının bir defaya mahsus değil, sürekli bir artışın olmasıdır. Bu bağlamda, enflasyon kavramının tanımı şu şekilde yapılabilir. İktisadi anlamda enflasyon; fiyatlar genel seviyesinde meydana gelen süreklilik gösteren ve önemli artışlar ya da bunun sebebi olarak görülen paranın değerinde meydana gelen sürekli düşüler şeklinde ifade edilmektedir (Eğilmez, 2015). 
Üstünde durulması gereken bir diğer konu ise, enflasyon oranlarındaki düşüştür. Enflasyon oranlarındaki düşüş mal ve hizmet fiyatlarında ortaya çıkan azalma olarak ifade edilmesi yanlış olacaktır. Enflasyon oranlarındaki düşme mal ve hizmet fiyatlarında daha az oranda bir artış olarak tanımlanabilir ve bunun neticesinde bireylerin alım gücü daha az azalmaya başlamaktadır (Merkez Bankas1, 2004).

Enflasyon çeşitli sebeplerle düşebilir. Öncelikle enflasyona sebep olan faktörlerde tersi değişimler meydana gelirse enflasyon düşmektedir. Örneğin, talepte bir düşüş yaşanırsa, ihracatta ve arzda bir değişim olmadığında enflasyonda bir düşüş yaşanmaya başlar. Arzda bir artış yaşandığında ise, talep miktarında bir değişiklik meydana gelmediğinde enflasyonda bir düşüş yaşanmaya başlanır. Böyle bir durumda ülke riskinde gerilemeler ortaya çıkar ve ülke parası diğer ülke paralarına karşı güçlendirmeye başlar ise enflasyon düşmeye başlamaktadır (Atgür ve Altay, 2015). Enflasyonun düşmesine ek olarak sayılacak bir diğer etki de baz etkisidir. Baz etkisi; karşılaştırılan iki dönemin ilkinde herhangi bir sebeple sayılar veya oran üzerinde meydana gelen çok yüksek bir artış veya düşüşün karşılaştırmaya konu olan iki dönemin sonuçlarında yarattığı etkidir. Bahsedilen bu nedenlerle enflasyon oranlarında meydana gelecek düşüş faiz oranlarında da bir düşüşe sebep olmaktadır (Mercan ve Peker, 2013).

1970'li yılların ikinci yarısından sonra sürekli ve yüksek bir şekilde seyreden enflasyon oranlarıyla baş etmeye çalışan Türkiye ekonomisi söz konusu dönemde ekonomik istikrarsızlık ve büyüme oranlarındaki düşüş, bireylerin gelir oranlarında ortaya çıkan adaletsizlik ve refah seviyelerinde bir bozulmaya neden olmuştur (T.C. Merkez Bankac1, 2004). Meydana gelen yüksek enflasyon neticesinde fiyatlar genel seviyesinde ortaya çıkan artışlar hane halkının alım gücünü düşürmekte ve bu durum da bireylerin geçim sıkıntısı çekmesine sebep olmaktadır (Doğan, Eroğlu ve Değer, 2016).

Türkiye'nin bugünkü en önemli ekonomik sorunlarından biri olan yüksek enflasyon oranları ihracatçıdan sanayiciye, işçiden memur kesimine kadar olan yani toplumda var olan tüm bireyleri ilgilendirmektedir. Fiyat istikrarının sağlanamadığı ülkemizde bireylerin elde ettiği kazançlar enflasyon sebebiyle eritirken bu süreç hane halkının yaşam standartlarının gerisinde olmasına sebep olmaktadır. Enflasyon için gerçekleştirilen mücadelenin önemi fiyat istikrarını sağlamak ve yüksek ve sürdürülebilir bir büyümeyi yakalamaktır (T.C. Merkez Bankası, 2004). Hükümetlerin yaptıkları ekonomi politikalarının hedefi hane halkının daima yaşam standardını ve refahını arttırmak ve daha kaliteli bir yaşam sürmelerini sağlayabilmektir. Enflasyonla mücadele edebilmek için kullanılan fiyat istikrarının sağlanması bu hedef için kullanılmakta olan bir araç niteliğindedir (Doğan, Eroğlu ve Değer, 2016). Fiyatlar genel düzeyinde ortaya çıkacak olan istikrar ortamının sonucunda meydana gelen belirsizlikler ortadan kalkmaktadır. Aynı zamanda bu süreç hane halkının karar alma davranışlarında mantıklı olma, bireylerin ve firmaların yatırım, tasarruf ve tüketimlerinde uzun süreli kararlar almalarına yardım etmektedir ( T.C. Merkez Bankası, 2004).

Fiyat istikrarının elde edildiği bir ortamda reel faiz oranlarında bir düşme meydana gelirken beraberinde kredi piyasalarında da daha sağlıklı bir ortam olacak ve bununla birlikte üreticiler çok daha yüksek oranlarda kredi kullanabilmek amacıyla kredi talebini arttıracaklardır (T.C. Merkez Bankası, 2004). Fiyat istikrarı sağlandıktan itibaren işgücü piyasaları da düzene girecektir. Hane halk1 daha kalıcı ve kolay iş bulabileceklerdir (Doğan, Eroğlu ve Değer, 2016).Enflasyon oranlarında yaşanan düşüş ve istikrar sağlanması ile beraber pozitif etkiler iç piyasada ve dış piyasada etkisini gösterecektir. Dış piyasalardaki pozitif etkiler uzun süreli yabancı yatırımların sağlıklı ortamlarda ülkeye giriş yapmasıyla kendisini gösterecek ve bununla ülkenin uluslararası şekilde rekabet gücünün arttıracaktır (T.C. Merkez Bankas1, 2004).

Türkiye'de 1970'li yıllardan sonra enflasyon olgusu ortaya çıkan en önemli sorunlardan biri olmuştur. Enflasyon oranlarında görülen sürekli artış ekonominin üzerinde olumsuz sonuçlara yol açmıştır. Türkiye ekonomisi için alınan 24 Ocak 1980 kararlarıyla emisyon hacmini ve para arzını kontrol altına alabilmek için kredi ve para hacminde enflasyon oranlarının altında bir yükselmenin olmasın karar verilmiştir. Fakat kredi ve para hacmi 1984 döneminde enflasyon oranından daha da çok artmıştır. Bununla birlikte, 1988 döneminde meydana gelen kamu açıkları gerçekleştirilen para basma 
ile finanse edildiğinden dolayı hem bütçe açı̆̆ı hem de fiyatlar artmıştır. Yeniden bu yıllarda kamuda ortaya çıkan borçlanma gereksinimindeki artış nedeniyle sermaye hareketleri 1989 yılında serbest bırakılmış fakat bunun sonucunda iç borç stoku yükselmiştir (Yıldız ve Başar, 2018).

1994 döneminde enflasyon oranlarında meydana gelen artışların beraberinde iç borçlanma krizi ortaya çıkmıştır. Ayrıca alınan tedbirler yetersiz olduğu için sonraki yıllarda da enflasyon giderek yükselmiştir. Bu bağlamda 2000'li yıllara kadar meydana gelen bu olaylar enflasyonda artışa neden olmuştur. 2001 yılında Türkiye'de ortaya çıkan krizin ardından Güçlü Ekonomiye Geçiş Programı neticesinde T. C. Merkez Bankası tarafından 2002 ve 2005 yılları arasında farklı bir rejime geçilerek örtük enflasyon hedeflemesi rejimi uygulanmasına karar vermiştir. 2005 yılından itibaren T. C. Merkez Bankası enflasyon hedeflemesi rejiminin gerektirdiği koşulların sağlandığını ön görerek 2006 döneminde açık enflasyon hedeflemesi rejimi uygulamasına geçilmiştir. Gerçekleştirilen açık enflasyon hedeflemesi uygulamasındaki en önemli sebep fiyat istikrarının sağlanabilmesi ve bunun sürdürülebilir olmasıdır. Bahsedilen bu amaç neticesinde Merkez Bankası tarafından kısa vadeli faiz oranları para politikası aracı şeklinde kullanılmaktadır (Eroğlu vd., 2009).

Piyasa ekonomisindeki en önemli unsurlar arasında sayılabilen ve sermaye getirisini oluşturmakta olan faizler ekonomide yer alan bütün kesimleri yakından ilgilendirmekte ve beraberinde etkilemektedir. Özellikle de enflasyon oranları ile faiz oranları arasında bulunan ilişkinin yönü hakkında iktisatçıların arasında tam fikir birliğinin bulunmamasına karşın, enflasyon ve faiz oranları arasında oldukça yakın bir ilişkinin bulunduğu savunulmaktadır (Alacahan, 2011). Enflasyon ile faiz oranları arasında bulunan ilişkiyi tam olarak anlayabilmek için ilk olarak ne tür enflasyon ile karşı karşıya olduğumuzu bilmek gerekmektedir (Eğilmez, 2015).

Monetarist iktisatçılar, enflasyonun para arzındaki artıştan kaynaklandığını öne sürmektedirler. Para arzındaki bir artış aynı zamanda talebin artması demektir. Talep artarsa fiyatlar yükselmekte ve enflasyon oluşmaktadır. Arz yönlü iktisatçılar ise, enflasyonun yüksek vergiler ve sıkılaştırılmış denetimler gibi etkilerin sonucunda artan maliyetler ile maliyet enflasyonu kökenli ortaya çıktığını ileri sürmektedirler (Eğilmez, 2015).

Bununla birlikte enflasyon oranları ile faiz oranları arasında bulunan ilişkiyi açıklamakta olan teorilerden bir tanesi Irving Fisher tarafından 1930 yılında geliştirilen Fisher hipotezidir. Söz konusu hipoteze göre, beklenen enflasyon oranı ile nominal faiz oranı reel faiz oranlarında hiçbir etki yaratmazken beraber hareket etmektedirler. İktisadi karar birimlerinin meydana gelen fiyat artışlarının neticesinde nominal paranın satın alma gücünde ortaya çıkan azalmaları telafi etme istekleri Fisher'in ileri sürdüğü bu ilişkinin temelinde yatan sebeptir (Y1lanc1, 2009). Türkiye'deki enflasyon oranı ve faiz oranları arasında bulunan ilişki 1980 yılı öncesi ve 1980 yılı sonrası olmak üzere iki döneme ayrılmaktadır. 1980 yılı öncesinde faiz oranlarına uygulanan tavan sınırı devlet tarafından uygulanarak söz konusu tavan sınırının aşılmasına izin verilmemiştir. 1980 döneminde pozitif mevduatlı faiz uygulaması geçerli olmadığından dolayı kullanılmakta olan kredilere de pozitif faiz ödenememiştir. Bundan dolayı tasarruflar altın ve gayrimenkul gibi çeşitli alanlara kaymıştır. Bahsedilen tüketim ve harcamalardaki artışlarla beraber enflasyon oranları da artmıştır. 1980 yılından itibaren pozitif reel faiz rejimine geçilerek tasarrufa teşvik sağlamak, talebi daraltmak ve böylelikle fiyat artışlarının önüne geçmek amaçlanmıştır (Turgutlu, 2004).

Enflasyon oranları ile faiz oranları arasında bulunan ilişkinin ekonomi üzerine etkileri parasal aktarım mekanizması yardımıyla açıklanabilmektedir. Bu bağlamda parasal aktarım mekanizması, merkez bankalarının uyguladığı para politikalarının ekonomi üzerinde yarattığı etki toplam arzdan çok toplam talep üzerinde yarattı̆̆ 1 etki ile meydana gelmektedir. Aynı zamanda uzun vadede fiyat istikrarı sağlanabilmesi amacıyla birincil piyasa olarak adlandırılan para politikası kısa vadede ise çıktı ve talep açığı üzerinde iniş çıkışlara neden olabilmektedir. Bundan dolayı 1980'li yıllardan sonra merkez bankaları para politikalarının çıktı açığı, toplam talep ve enflasyonu ne şekilde etkilediğini açıklamak için parasal aktarım mekanizması kullanılmaktadır (T.C. Merkez Bankası, 2013).

\subsection{Enflasyon ve Faiz Oranı Ayarlamaları}


Enflasyonla mücadele etmek ve fiyat istikrarını sağlayabilmek için enflasyon hedeflemesi yapan yapmakta olan merkez bankaları faiz oranlarını temel araç olarak kullanmaktadırlar (Yıldız ve Başar, 2018).Parasal aktarım mekanizması varlık fiyatları kanalı, faiz oranı kanalı, döviz kuru kanalı ve beklentiler kanalından oluşmaktadır. Bu kanallardan ilkine göre; Merkez Bankası'nın faiz oranlarına yaptığı veya yapacağı değişiklikler sonucunda finans ve banka kuruluşları Merkez Bankası'nın yapmış oluğu değişiklikleri dikkate alarak faiz kararlarını vereceklerdir. İkinci kanala göre; piyasa faiz oranlarında meydana gelen değişmelerin bankalardan sağlanan döviz ve hisse senedi gibi varlıkları etkilediği gibi pek çok varlıkların da fiyatlarını etkileyerek değişmelere neden olmaktadır. Üçüncü kanala göre; Merkez Bankaları'nın faiz oranlarıyla ilgili aldıkları kararlar firmaların ve bireylerin beklentilerini etkilerken aynı zamanda verecekleri kararları da etkilemektedirler. Dördüncü kanal ise; yurtiçindeki ve yurtdışındaki faizler ülkeye çekilen yabancı sermayede etkilidir (Doğan vd., 2016).

Merkez Bankası'nın değiştirdiği faiz oranlarının ekonomi ile uyum süreci oldukça zaman almaktadır. Uygulanmakta olan kanalların bazıları söz konusu diğer kanalara göre kıyaslandığında uyum sürecine etkileri daha kısa vadeli olabilmektedir. Bu bağlamda aktarım mekanizması kanallarının bazılarının etkilerinin diğer kanallara göre daha hızlı olarak görüldüğünü söyleyebiliriz. Bahsedilen bu kanal etkilerinin genel anlamda uygulanmakta olan politikalarda yapılan değişikliklerin ne derecede bir gecikme ile etki yarattığı hane halkının tasarruf, tüketim ve yatırımlarındaki değişikliklere bağlıdır. Bununla birlikte aktarım mekanizması kanallarının ne ölçüde ve ne kadar bir sürede etki yaratacağını belirlemek ve bunu öngörmek oldukça zordur. Bu sebeple Merkez Bankaları faiz kararlarını alırken enflasyon oranlarının cari değerine göre değil gelecek dönemdeki değerlerine göre alınmaktadır (Alacahan, 2011).

\section{Literatür Taraması}

Atgür ve Altay (2015) tarafından yapılan çalışmada, Türkiye için enflasyon oranları ile nominal faiz oranları arasında bulunan ilişkiyi test edebilmek için 2004 ve 2013 dönemi verileri kullanılmıştır. Çalışmadan elde edilen sonuçlara göre, 2004 ve 2013 döneminde Fisher Etkisinin Türkiye' de geçerli olduğu görülmüştür. Çalışmada yapılan Dinamik En Küçük Kareler Yöntemi ve LütkepohlSaikkonen, Johansen eşbütünleşme Testleri sonucuna göre enflasyon oranları (ENF) ile nominal faiz oranları (NFO) değişkenlerinin arasında bir uzun dönem ilişkisi olduğu tespit edilmiştir. Bu bağlamda 2004 ve 2013 dönemi için Türkiye'de enflasyon oranları ile nominal faiz oranlarındaki gelişmeler birbirlerini yakından ilgilendirdiği sonucuna varılmıştır.

Mercan ve Peker (2013) tarafından yapılan çalışmada, Türkiye'deki faiz oranları ile enflasyon oranları arasında bulunan ilişki 1992 ve 2013 yılları arasındaki aylık veriler kullanılarak incelenmiştir. ARDL Sınır Testi yöntemi kullanılarak yapılan çalışmada elde edilen sonuçlara göre, Türkiye'de faiz oranları ile enflasyon arasında bir ilişkinin söz konusu olmadığı sonucuna varılmıştır.

Torun ve Karanfil (2016) tarafından yapılan çalışmada, Türkiye ekonomisinin 1980-2013 dönemi verileri kullanılarak enflasyon oranları ile faiz oranları arasında bulunan ilişki analiz edilmiştir. Kurulan modellerde reel döviz kuru, GSYİH ve faiz oranı değişkenlerinin enflasyon oranları üzerinde meydana getirdiği etki incelenmiştir. Enflasyon oranı bağımlı değişken olarak, reel döviz kuru, GSYİH ve faiz oranları bağımsız değişken olarak kullanılmıştır. Çalışma söz konusu değişkenler arasında bulunan ilişki Granger nedensellik, Johansen eşbütünleşme ve varyans ayrıştırma yöntemleri ile analiz edilmiştir. Elde edilen sonuçlara göre modelde kullanılan değişkenler arasında uzun vadeli bir ilişkinin bulunduğu görülmüştür. GSYİH ile faiz oranından enflasyona doğru nedensellik ilişkisinin olduğu sonucuna varılmıştır. Aynı zamanda GSYİH ve faiz oranı arasında çift yönde nedensellik ilişkisi olduğu sonucu elde edilmiştir.

Akıncı ve Yılmaz (2015) tarafından yapılan çalışmada, Türkiye ekonomisi için 1980-2012 dönemi verileri kullanılarak enflasyon oranlarının faizlere etkileri Dinamik En Küçük Kareler yöntemiyle analiz edilmiştir. Öncelikle, değişkenlere Johansen eşbütünleşme testi uygulanmış ve analiz sonucunda, uzun vadeli ilişkiler tespit edilmiştir. Değişkenler arasındaki nedensellik ilişkisi Granger 
nedensellik testi uygulanmıştır. Test sonucunda beklentiler ile uyum içinde olan nedensellik ilişkisinin bulunduğu görülmüştür. Dinamik En Küçük Kareler analizine göre; cari denge, enflasyon, para arzı, dış borç servisi, ekonomik büyüme süreci ve döviz kurunun faiz oranlarına olan etkisi istatistiksel olarak anlamlı etki yarattığı sonucuna varılmıştır.

Yılancı (2009) tarafından yapılan çalışmada, Türkiye ekonomisi için Fisher Hipotezi’nin geçerliliği 1989 ile 2008 yılları arasındaki dönemin üç aylık verileri kullanılarak incelenmiştir. Engle Granger eşbütünleşme Testi ve doğrusal olmayan eşbütünleşme testi yöntemleri sonuçlarına göre, Türkiye ekonomisinde Fisher Hipotezinin geçerli olmadığı tespit edilmiştir.

Tunalı ve Erönal (2016) tarafından yapılan çalışmada, faiz oranları ile enflasyon arasındaki uzun dönem ilişkisinin varlığını ifade eden Fisher Hipotezinin, Türkiye'de geçerliliği araştırılmıştır. Çalışmada, yapısal kırılmanın varlığında enflasyon oranı ve faiz oranları serileri arasındaki ilişki incelenmiştir. Enflasyon ve faiz oranları arasındaki ilişki 2003:1-2014:2 yıllarına ilişkin on iki aylık veriler kullanılmıştır. Analizde yapısal kırılmanın olup olmadığı Gregory- Hansen Eş bütünleşme testi kullanılarak yapılmıştır. Uygulanmış olan bu testlerin sonucunda, Türkiye için uzun dönemde Fisher Etkisinin geçerli olduğu ve kısa dönemde geçerli olmadığı tespit edilmiştir.

Kesriyeli (1994) tarafından yapılan çalışmada, Türkiye ekonomisi için 1980-1993 dönemlerine ilişkin veriler kullanılarak Johansen eşbütünleşme Analizi ile nominal faiz oranları ve enflasyon arasında uzun dönemli bir ilişkinin var olduğunu göstermektedir.

Berument vd. (2007) tarafından yapılan çalışmada, gelişmekte olan 45 ülkede ve G7 ülkelerinde, beklenen enflasyon ile faiz oranları arasında pozitif yönlü bir ilişki kuran Fisher Hipotezinin geçerli olup olmadığı analiz edilmiştir. Farklı dönemlerin göz önünde bulundurulduğu ve GARCH Modeli yönteminin kullanılan çalışmanın sonucunda, G7 ülkelerinde Fisher etkisinin geçerli olduğu, gelişmekte olan 45 ülkeden ise üç tanesinde geçerli olduğu görülmüştür. 6 tane G7 ülkesinde ve gelişmekte olan 18 ülkede enflasyon belirsizliği ile faiz oranları arasında anlamlı ve pozitif bir ilişkinin var olduğunu, 7 tane gelişmekte olan ülkede ise negatif yönlü bir ilişkinin söz konusu olduğu ortaya konmuştur.

Teker vd. (2012) tarafından yapılan çalışmada, Türkiye ekonomisindeki faiz oranları ile enflasyon oranları arasında bulunan uzun dönem ilişkisi 2002 ile 2011 yılları arası dönem için incelenmiştir. Tüketici Fiyat Endeksi ve mevduat faiz oranları değişkenlerinin incelendiği analizde eşik hata düzeltme modeli uygulanmıştır. Modelin tahmin sonuçlarına göre, Türkiye'de ele alınmakta olan süreçte enflasyon ve faiz oranı arasında uzun dönem ilişkisinin var olduğu sonucuna ulaşılmıştır.

Mc Kenzıe (1998) tarafından yapılan çalışmada, İsrail ekonomisindeki beklenen enflasyon ile reel faiz oranları arasında bulunan ilişkiyi 1984-1992 arası dönem için araştırmıştır. Regresyon modeli tahmin sonuçlarından elde edilen bulgulara göre, İsrail ekonomisindeki belenen enflasyon ile reel faiz oranları arasında ters yönlü bir ilişkinin bulunduğu ortaya konmuştur.

Eren (2002) tarafından yapılan çalışmada, 2002 ve 2011 dönemleri arasında Fisher Etkisinin Türkiye'de geçerli olup olmadığı doğrusal olmayan eşbütünleşme yöntemiyle analiz edilmiştir. Çalışmada 2002- 2011 yıllarına ilişkin aylık veriler kullanılmıştır. Faiz oranı değişkeni için ay, üç ay, altı ay ve on iki ay şeklinde ağırlıklandırılmış vadeli mevduatlar için uygulanmakta olan Tüketici Fiyat Endeksleri (TÜFE) ve nominal faiz oranları değişkenleri kullanılmıştır. Doğrusal olmayan eşbütünleşme yönteminden elde edilen sonuçlara, söz konusu dönemde Türkiye'deki enflasyon hedeflemesi ve dalgalı kur rejimi uygulamaları nedeniyle Fisher Etkisi'nin geçersiz olduğu sonucuna ulaşılmıştır.

Şimşek ve Kadılar (2006) tarafından yapılan çalışmada, Türkiye'de Fisher etkisinin olup olmadığını analiz etmek için 1987-2004 aylık verileri kullanılmıştır. Fisher Etkis'nin var olup olmadığını incelemek için ARDL (Auto regressive Distributed Lag) testi ile analiz edilmiştir. Çalışma sonucunda elde edilen sonuçlara göre Türkiye ekonomisinde Fisher Etkisi’nin varlığı tespit edilmiştir.

Bhar ve Mallik (2012) tarafindan yapılan çalışmada, Yeni Zelanda ve Avustralya ekonomisinde faiz oranları ve enflasyon belirsizlikleri arasındaki ilişki incelenmiştir. Çalışmada 1957-2006 dönemine 
ilişkin üçer aylık veriler GARCH modeli yöntemi ile tahmin edilmiştir. Analizde nominal faiz oranlarının, enflasyon belirsizliği, beklenen enflasyon ve çıktı açığını ne derecede etkilediği üzerine yoğunlaşılmıştır. Analizden elde edilen bulgulara göre, hem Yeni Zelanda'da hem de Avustralya'da nominal faiz oranları ile enflasyon arasında pozitif yönlü bir ilişkinin bulunduğu görülmüştür. Ayrıca iki ülkede de etkilerin belirsiz olması bileşeninin faiz oranlarındaki etkisi anlamsız bulunmuştur.

Mackinnon (1996) tarafından yapılan çalışmada, Malezya ekonomisine ilişkin 2000-2012 veriler kullanılarak Fisher Etkisinin geçerli olup olmadığı incelenmiştir. Çalışmada aylık ve üç aylık faiz oranları, interbank faiz oranı, Tüketici Fiyat Endeksi hazine bonosu ve değişkenleri kullanılmıştır. Değişkenler arasındaki ilişkiyi analiz edebilmek için kullanılan ARDL Sınır Testi sonuçlarına göre, uzun dönem için Malezya'nın para piyasasında Fisher Etkisi'nin var olduğu sonucuna varılmıştır.

\section{EKONOMETRİK ANALIZZ}

İktisadi durumlar ile iktisadi sorunları sayısal bir ifade ile kullanmak ve ortaya koymak iktisadi kararların doğru bir biçimde alınmasında yardımcı olmaktadır. Bu yüzden iktisadi ifadelerde ekonometrik analize ihtiyaç duyulmaktadır. Yapılan çalışmada, pratik ve teori arasında yakın bir ilişkinin kurulup analiz edilmesi için ekonometrik yöntem uygulanmaktadır. Ekonometrik analizden elde edilen sonuçlara göre, literatürde yer alan diğer çalışmaların sonuçlarının aynı yönde olup olmadığı değerlendirilmektedir. Bu çalışmada, enflasyon oranları ile faiz oranları arasında bir ilişsinin olup olmadığı sonucuna ulaşabilmek amacıyla, 2003-2018 yılları arasındaki sürece ilişkin verilerin istikrarlı bir şekilde olmadığı göz önünde bulundurularak, 2003:1-2018:4 dönemine ait aylık veriler kullanılarak, enflasyon oranları ile faiz oranları arasındaki ilişki incelenmiştir.

\subsection{BİRIM KÖK TESTİ}

\subsubsection{ADF Birim Kök Testi}

Çalışmada enflasyon ile faiz oranları değişkenleri arasındaki ilişkinin durağan olup olmadığını analiz etmek için Phillips Perron (PP) ve Augmented Dickey Fuller (ADF) birim kök testleri uygulanmıştır. Yapılan birim kök testlerine göre enflasyon ile faiz oranları değişkenlerinin serilerinin modelde durağan olduğu sonucuna varılmıştır.

Tablo 1: Augmented Dickey Fuller (ADF) Birim Kök Testi Sonuçları

\begin{tabular}{|l|l|l|l|l|}
\hline \multirow{2}{*}{ Değişken } & ADF Test İstatistiği & \multicolumn{3}{l|}{ Kritik Değerler } \\
\cline { 3 - 5 } & & $\mathbf{\% 1}$ & $\mathbf{\% 5}$ & $\mathbf{\% 1 0}$ \\
\hline Ln ENFSA & -2.99 & -4.02 & -3.44 & -3.14 \\
\hline $\boldsymbol{\Delta}$ Ln ENFSA & -10.74 & -3.47 & -2.88 & -2.57 \\
\hline Ln DỉBSSA & -3.09 & -4.02 & -3.44 & -3.14 \\
\hline $\boldsymbol{\Delta}$ Ln DïBSSA & -14.89 & -3.47 & -2.88 & -2.57 \\
\hline
\end{tabular}

Tablo 1'de ADF (Augmented Dickey Fuller) birim kök testi ile dolaylı vergi " DİBS' ve enflasyon " ENF” değişkenlerinin serileri durağan olup olmadı̆̆ elde edilen bulgulara göre dolaylı vergi "DİBS" değişkeninin sabitli, sabitli- trendli ve sabitsiztrendsiz modellerde durağan olduğu ortaya konmuştur. Enflasyon " ENF” değişkeni içinse sabitli, sabitli - trendli ve sabitsiz- trendsiz modellerinin durağan bir seri olmadığı sonucuna varılmıştır. Tablo 1'de serinin farkı alınarak seri durağan hale getirilmiştir. Yapılan Augmented Dickey Fuller (ADF) birim kök testleri uygulanmıştır. Yapılan birim kök testlerine göre enflasyon ile faiz oranları değişkenlerinin serilerinin modelde durağan olduğu sonucuna varılmıştır. 


\subsubsection{Phillips Perron Birim Kök Testi}

Tablo 2: PP Birim Kök Testi Sonuçları

\begin{tabular}{|c|c|c|c|c|c|c|}
\hline & \multicolumn{2}{|c|}{ SABİTLİ } & \multicolumn{2}{|c|}{ SABİTLİ- TRENDLİ } & \multicolumn{2}{|c|}{ SABİTSİZ- TRENDSİZ } \\
\hline & t- Statistic & Prob & t- Statistic & Prob & t- Statistic & Prob \\
\hline $\begin{array}{l}\text { ENFLASYON } \\
\text { ORANLARI } \\
\text { (ENF) }\end{array}$ & -1.0629 & -0.7851 & -4.5478 & 0.0347 & 6.8621 & 1.0000 \\
\hline $\begin{array}{l}\text { DİBS: } \quad \text { Nakit } \\
\text { Borçlanma Aylık } \\
\text { Ortalama } \\
\text { Maliyet(Yıllık } \\
\text { Bileşik \%) }\end{array}$ & -0.5748 & 0.6574 & -0.5265 & 0.9305 & 0.9736 & 0.7668 \\
\hline
\end{tabular}

Tablo 2'de Phillips-Peron (PP) birim kök testinde ise yapılan analize göre, düzey değerlerde enflasyon "ENF" değişkeninin prob değerleri incelendiğinde sabitli modelde "ENF" prob değeri 0.10 değerinin üzerinde olduğu için seri durağan değildir, sabitli trendli modelde de seri durağan değildir, sabitsiz- trendsiz modelde ise durağan bir seri olduğu ortaya konmuştur. Dolaylı vergi “" DİBS" değişkeninin değerleri incelendiğinde ise sabitli, sabitli- trendli ve sabitsiz- trendsiz modellerinde serinin durağan olduğu sonucuna varılmıştır. Seriyi durağan hale getirmek için Tablo 1' deki Augmented Dickey Fuller (ADF) birim kök testi serisinin farkı alınmıştır.

Tablo 3: Farkı Alındıktan Sonra PP Birim Kök Testi Sonuçları

\begin{tabular}{|l|l|l|l|l|l|l|}
\hline & \multicolumn{2}{|l}{ SABITLI } & \multicolumn{2}{l|}{ SABITLI- TRENDLI } & \multicolumn{2}{l|}{ SABÍTSİ- TRENDSİ } \\
\cline { 2 - 7 } & t- Statistic & Prob & t- Statistic & Prob & t- Statistic & Prob \\
\hline $\begin{array}{l}\text { DOLAYLI } \\
\text { VERGI } \\
(\text { DV) }\end{array}$ & -1.0877 & $\mathbf{- 0 . 7 6 6 8}$ & -4.3664 & $\mathbf{0 . 0 3 7 4}$ & 6.8353 & $\mathbf{1 . 0 0 0 0}$ \\
$\begin{array}{l}\text { ENFLASYON } \\
\begin{array}{l}\text { ORANLARI } \\
\text { (ENF) }\end{array}\end{array}$ & -0.6865 & $\mathbf{0 . 7 4 8 9}$ & -0.5278 & $\mathbf{0 . 8 6 2 5}$ & 0.9634 & $\mathbf{0 . 7 6 8 9}$ \\
\hline
\end{tabular}

TABLO 3'de serinin farkı alınarak durağan hale getirilmiştir. Seri bu haliyle sabitli, sabitli-trendli ve sabitsiz- trendsiz modelde birim kök içermez. H0 reddir. 


\subsection{Granger Nedensellik Testi}

Tablo 4: Granger Nedensellik Testi Sonuçları

\begin{tabular}{|c|c|c|}
\hline DEĞISŞKENLER & F-İSTATÍSTIĞí & OLASILIK DEĞERI \\
\hline $\begin{array}{l}\text { ENFLASYON } \\
\text { ORANLARI } \rightarrow \text { FAİZ ORANLARI } \\
(\text { ENF) } \rightarrow(\text { DIBS })\end{array}$ & 4.85696 & 0.0869 \\
\hline $\begin{array}{l}\text { FAİZ } \\
\text { ORANLARI } \rightarrow \text { ENFLASYON } \\
\text { ORANLARI } \\
(\text { DIBS }) \rightarrow(\text { ENF })\end{array}$ & 1.68797 & 0.3681 \\
\hline
\end{tabular}

Tablo 4'te Granger Nedensellik Testi sonuçları verilmiştir. Enflasyon oranları faiz oranlarını etkilerken, faiz oranlarının enflasyon üzerinde bir etkisi bulunmamaktadır. Enflasyon ile faiz oranları arasında tek taraflı bir nedensellik ilişkisi olduğu sonucuna ulaşırız.

\subsection{JOHANSEN KOENTEGRASYON ANALIZİ}

Tablo 5: JohansenEşbütünleşme Testi Sonuçları

\begin{tabular}{|l|l|l|l|l|}
\hline Hipotez & Traceİstatstiği & Kritik Değer (\%5) & $\begin{array}{l}\text { Max-Eigen } \\
\text { İstatistiği }\end{array}$ & Kritik Değer (\%5) \\
\hline H0: $\boldsymbol{\tau}=\mathbf{0}, \mathbf{H 1}: \boldsymbol{\tau}=\mathbf{1}$ & 24.90 & 25.87 & 16.59 & 19.38 \\
\hline H0: $\boldsymbol{\tau} \leq \mathbf{1}, \mathbf{H 1 :} \boldsymbol{\tau = \mathbf { 2 }}$ & 8.30 & 12.51 & 8.30 & 12.51 \\
\hline
\end{tabular}

Yapılan analizden elde edilen sonuçlara göre hesaplanmış olan test istatistiklerinin değerleri kritik değer olan $\% 1, \% 5$ ve $\% 10$ değerlerinden küçük olduğundan dolayı H0 hipotezini kabul ederiz. Bu bağlamda serilerin arasında bir eşbütünleşme ilişkisinin var olmadı sonucuna varılmaktadır. Dolayısıyla söz konusu seriler uzun dönemde beraber hareket etmemektedir. Söz konusu serilerin düzey değerleri ile yapılmakta olan uzun dönem analizi, sahte regresyon sorununu meydana getirecektir.

Söz konusu serilerin arasında eşbütünleşme ilişkisi var olmadığın sonucuna ulaşılmıştır. Araştırmanın desteklenmesi için değișen varyans sorunu, otokorelasyon testleri yapılmıștır. Serilerdeki otokorelasyon problemine bakıldığında 13. gecikmede otokorelasyon probleminin var olmadığı ve bununla birlikte değișen varyans problemine bakılarak değişen varyans probleminin bulunmadığı sonucuna varılmıştır.

\section{Sonuç}

Yapılan bu çalışmada 1980:1- 2018:4 dönemlerindeki aylık verilere ilişkin faiz oranları ve enflasyon oranları arasındaki nedensellik ilişkisi analiz edilmiş ve araştırılmıştır. Enflasyon oranları verileri için TÜFE, faiz oranları verileri içinse (DİBS) Devlet İç Borçlanma Senetleri Faiz Oranları kullanılmıştır. Yapılan analizlerin sonucunda meydana gelen bulgular neticesinde enflasyon oranlarından faiz oranlarına doğru nedensellik ilişkisi bulunurken, faiz oranlarından enflasyon oranlarına doğru ise bir nedensellik ilişkisinin olmadığ 1 sonucuna varılmıştır.

T. C. Merkez Bankası para kurulunun belirlediği faiz oranlarının aktarım kanalları yardımıyla enflasyon oranlarını etkilerken, faiz oranının uyum dönemlerinde gecikmeler meydana geleceği için faiz oranlarında ortaya çıkan değișmelerin enflasyon oranları üzerindeki etkisi zaman almaktadır. Aktarım mekanizması kanallarındaki çeşitlilik ve uyum döneminin zaman alması nedeniyle faiz oranının enflasyon oranlarını ne kadar etkileyeceği belirli olmamaktadır.

Sonuç olarak, enflasyon oranları ile faiz oranları arasında bulunan nedensellik ilişkisinin faiz oranları konusunda belirlenmesi açısından çok dikkat edilmesi gerekmektedir. 2001 yılı sonrasında Güçlü Ekonomiye Geçiş Programı ile enflasyon hedeflemesi uygulamasına geçilmiş, beraberinde enflasyon oranlarındaki azalmalar ortaya çıkmaktadır. Bu bağlamda bu durum neticesinde faiz oranlarındaki düşüş enflasyon oranları 
ile ilişkilendirilebilmektedir. Yapılan bu çalışmada da enflasyon oranlarındaki değişimler sonucunda faiz oranındaki değişimlerin ortaya çıktığı açıklanmaya çalışılmıştır.

\section{Kaynakça}

Akınc1, M., Yüce Akıncı, G., \& Yılmaz, Ö. (2015). Terörizmin Doğrudan ve Dolaylı Yatırımlar Üzerindeki Etkisi: Dış Yardımlar Ne Kadar Telafi Edici.

Alacahan, N. D. (2011). Enflasyon, Döviz Kuru İlişkisi ve Yansıma: Türkiye The Relatoınshıp Between Inflation, Exchange Rate and Pass Through: Turkey. Sosyal Bilimler Dergisi, (1), 49-56.

Atgür, M., \& Altay, N. O. (2015). Enflasyon ve Nominal Faiz Oranı İliskisi: Türkiye Örneği (20042013)/Relationship Between The Inflation and Nominal Interest Rate: The Case of Turkey (20042013). Yönetim ve Ekonomi, 22(2), 521.

Berument, H. ve Jelassi, M.M. (2002). The Fisher Hypothesis: A Multi-Country Analysis. Applied Economics, (34), 1645-1655.

Bhar, R. ve Mallik, G. (2013). İngiltere'de Enflasyon Belirsizliği, Büyüme Belirsizliği, Petrol Fiyatları ve Üretim Artışı. Ampirik Ekonomi , 45 (3), 1333-1350.

Dickey, D.A. (1981). Histograms, Percentiles, and Moment. American Statistician, 35, 164-165.

Dickey, D.A. ve Fuller, W.A. (1979). Distribution of The Estimates For Auto Regressive Time Series With A Unitroot. Journal of Econometrics, 2(2), 111-120.

Doğan, B., Eroğlu, Ö., \& Değer, O. (2016). Enflasyon ve Faiz Oranı Arasındaki Nedensellik İlişkisi: Türkiye Örneği. Çankırı Karatekin Üniversitesi İÏBF Dergisi, 6(1), 405-425.

Eğilmez, M. (2015). Http://Www.Mahfiegilmez.Com/2015/

Engle, R.F. ve Granger, W.J. (1987). Cointegartion and Error Correction: Representation, Estimation, and Testing. Econometrica, 55, 107-123.

Eren, A. (2002). Türkiye'nin Ekonomik Yapısı ve Güncel Sorunlar. Muğla: Muğla Üniversitesi Yayını.

Eroğlu, F. (2009). Davranış Bilimleri . Beta Basım Yayım Dağıtım.

Granville, B. ve Mallick, S. (2004). Fisher hypothesis: UK Evidence Over A Century. Applied Economics Letters, 11(2), 87-90.

Kesriyeli, M. (1994). Policy Regime Changes And Testing For The Fisher and UIP Hypotheses: The Turkish Evidence (No. 9411).

Mackinnon, J.G. (1996). Numerical Distribution Functions For Unit Root Andc Ointegration Tests. Journal of Applied Econometrics, 11, 601-618.

Mc Kenzie, D.M. (1998). The 1mpact Of Exchange Rate Volatility On Australian Trade Flows. Journal Of Economic Survey, 13(1), $71-106$.

Mercan, M., \& Peker, O. (2013). Finansal Gelişmenin Ekonomik Büyümeye Etkisi: Ekonometrik Bir Analiz. Eskişehir Osmangazi Üniversitesi İktisadi ve İdari Bilimler Dergisi, 8(1), 93-120.

Perron, P. (1990). Testing For A Unit Root In A Time Series With A Changing Mean. Journal Of Business And Economic Statistics, 8, 153-62.

Phillips, P.C.B. (1988). Testing For A Unitroot In Time Series Regressions. Biometrika, 75, 335-346.

Şimşek, M. Ve Kadılar, C. (2006). Fisher Etkisinin Türkiye Verileri İle Testi. Doğuş Üniversitesi Dergisi, 7(1), 99-111.

TCMB (2004), 2004 Enflasyon Raporu, Ankara.

TCMB (2013), 2013 Enflasyon Raporu, Ankara

Teker, D., Alp, E. A., \& Kent, O. (2012). Long-Run Relation Between Interest Rates And Inflation: Evidence From Turkey. Journal Of Applied Finance And Banking, 2(6), 41. 
Tunalı, H., \& Erönal, Y. Y. (2016). Enflasyon Ve Faiz Oranı İlişkisi: Türkiye'de Fısher Etkisinin Geçerliliği. Suleyman Demirel University Journal Of Faculty Of Economics \& Administrative Sciences, 21(4).

Turgutlu, E. (2004). Fisher Hipotezinin Tutarlılığının Testi: Parçalı Durağanlık ve Parçalı Koentegrasyon Analizi, Dokuz Eylül Üniversitesi İ̈BF Dergisi, 19(2), 55-74.

Turhan, S.A. (2007). Enflasyon ve Ekonomik Büyüme İlişkisi: Türkiye Örneği. Yayınlanmamış Yüksek Lisans Tezi, Kahramanmaraş: Sütçü İmam Üniversitesi Sosyal Bilimler Enstitüsü.

Torun, M., \& Karanfil, M. (2016). 1980-2013 Dönemi Türkiye Ekonomisinde Enflasyon ve Faiz Oranı Arasındaki İlişki.

Yılanc1, V. (2009). Fisher Hipotezinin Türkiye İçin Sınanması: Doğrusal Olmayan Eşbütünleşme Analizi. Atatürk Üniversitesi İ̈BF Dergisi, 23(4), 205-213.

Yıldız, Ş., \& Başar, S. (2018). Türkiye'de Enflasyon, Faiz Oranı ve Döviz Kuru Arasındaki İlişsinin Nedensellik Analizi. Electronic Turkish Studies, 13(7). 